\title{
ОБЩЕСТВЕННЫЕ ФИНАНСЫ
}

DOI: $10.15838 / \mathrm{esc} / 2015.1 .37 .10$

УДК 336.14(470.12), ББК 65.261.713(2Рос-4Вол)

(С) Поварова А.И.

\section{Региональный бюджет 2015-2017: бездефицитность или отказ от развития?}

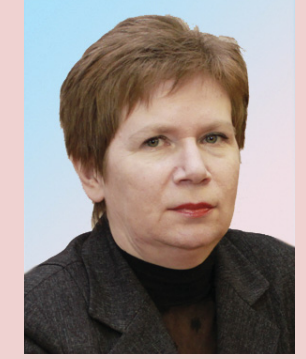

\begin{abstract}
Анна Ивановна
ПОВАРОВА

старший научный сотрудник, зав. сектором исследования проблем общественных финансов, Федеральное государственное бюджетное учреждение науки Институт социально-экономического развития территорий Российской академии наук (160014, г. Вологда, ул. Горького, д. 56а, aip150663@yandex.ru)
\end{abstract}

Аннотация. Формирование регионального бюджета Вологодской области на 2015-2017 годы проходило в сложных социально-экономических условиях, вызванных не только сохраняющейся высокой зависимостью российской экономики и бюджетной системы от внешнеэкономической конъюнктуры, но и целым рядом новых факторов, связанных с усилением геополитической напряжённости и введением секторальных санкций западными странами.

Несмотря на неопределённость трендов развития экономики, новый бюджет объявлен бездефицитным. Казалось бы, достигнут основополагающий принцип бюджетной системы - сбалансированность доходов и расходов. Однако анализ расходной части бюджета показал, что ценой баланса выступает режим жёсткой экономии, переходящий в рестрикцию всех направлений финансирования. За 2015-2017 гг. доля расходов областного бюджета в ВРП уменьшится до 9,8\% против 13,6\% в 2014 г. При нисходящей макроэкономической динамике такая бюджетная политика в долгосрочном периоде будет ещё больше подавлять экономику и в конечном итоге приведёт к сокращению налогового потенциала.

В условиях замедления экономической активности, даже при сбалансированном бюджете, не удастся полностью нивелировать циклические риски поступления налога на прибыль от интегрированных в мировую экономику крупнейших бюджетообразующих отраслей региона металлургической и химической. Простые расчёты дают основание говорить о том, что при уже имеющемся высоком уровне закредитованности правительству области крайне трудно будет преодолеть зависимость от привлекаемых средств, поэтому достижение бюджетного баланса в прогнозном периоде выглядит весьма иллюзорным. 
На основе результатов анализа ряда законов об областном бюджете ${ }^{1}$ автор приходит к выводу об ошибочности проводимого федеральным правительством курса налогово-бюджетной политики, приматом которого являются фискальные, а не стимулирующие и регулирующие функции, способствующие экономическому росту.

Нарастание проблем на региональном уровне рано или поздно потребует принятия решений со стороны центра.

В статье обосновываются практические рекомендации по стабилизации территориальных бюджетных систем, которая одновременно должна сопровождаться принятием мер по корректировке налогово-бюджетной политики.

Ключевые слова: региональный бюджет, дефицит, кредиты, долговая нагрузка, корректировка налогово-бюджетной политики.

В ближайшие годы как мировая, так и российская экономика сохранит невысокие темпы роста. При этом рост экономики РФ будет значительно ниже роста мировой экономики. Неопределённость макроэкономических трендов может возрастать в связи с прогнозируемым понижением ключевого параметра формирования бюджетных доходов - цен на нефть (puc. 1).

Прогноз экономического и социального развития Вологодской области на 20152017 гг. [11], отражающий общероссийские тенденции, характеризуется стагнацией всех макроэкономических показателей на фоне сильного спада инвестиционной активности (табл. 1).

Роста ВРП в 2015-2017 гг. предполагается достичь за счёт увеличения промышленного производства и потребительского спроса. Однако, на наш взгляд, существуют риски недостижения прогнозируемых значений ВРП, которые не увязываются с отрицательной динамикой инвестиций в основной капитал. Ожидается, что в 2017 г. капиталовложения сократятся на 23,2\% по сравнению с уровнем 2014 г., что предопределяет замедление темпов роста ВРП.

Безусловно, экономические проблемы не могут не отразиться на состоянии бюджетной системы региона, хотя на первый взгляд, основные параметры нового трёхлетнего бюджета [10] выглядят весьма оптимистично.

Прогнозируется рост как общих, так и собственных доходов. Но сами по себе абсолютные показатели мало о чём говорят. Системной ошибкой бюджетного планирования на региональном уровне является отсутствие корреляции основных параметров бюджета с ВРП. По нашим расчётам, доля доходов регионального бюджета в ВРП уменьшится до 10,7\% в 2017 г. против 12,5\% в 2014 г., что указывает на долгосрочный дефицит финансовых ресурсов (табл. 2).

1 Поварова А.И. Формирование регионального бюджета в условиях кризиса // Экономические и социальные перемены: факты, тенденции, прогноз. - 2010. - № 2. - С. 101-114; Поварова А.И. Трёхлетний бюджет: ждать ли стабильности? // Там же. - 2011. - № 2. - С. 20-36; Поварова А.И. Региональный бюджет 2012-2014: стабильность откладывается // Там же. - 2012. - № 3. - С. 39-58; Поварова А.И. Региональный бюджет 2013-2015: стабильность или выживание? // Там же. - 2013. - № 1. - С. 36-55.

2 Согласно новому прогнозу Минэкономразвития РФ от 31.01.2015 г., падение ВВП составит 3\% (в предыдущем прогнозе $0,8 \%$ ). Инфляция на конец года ожидается на уровне $12 \%$ вместо запланированных ранее 7,5\%. Снижение инвестиций предусмотрено в размере $13 \%$, реальных располагаемых доходов населения - на $6 \%$ (ранее эти показатели прогнозировались со снижением соответственно на 3,5 и 2,8\%).

Сценарный прогноз на 2015 г., разработанный учёными Института народнохозяйственного прогнозирования РАН, предусматривает снижение ВРП в стрессовом варианте на 4\%, в консервативном - на 2,5\%, в оптимистическом - на $0,3 \%$ 
Рисунок 1. Темпы прироста мировой и российской экономики, цена на нефть в 2010-2017 гг.

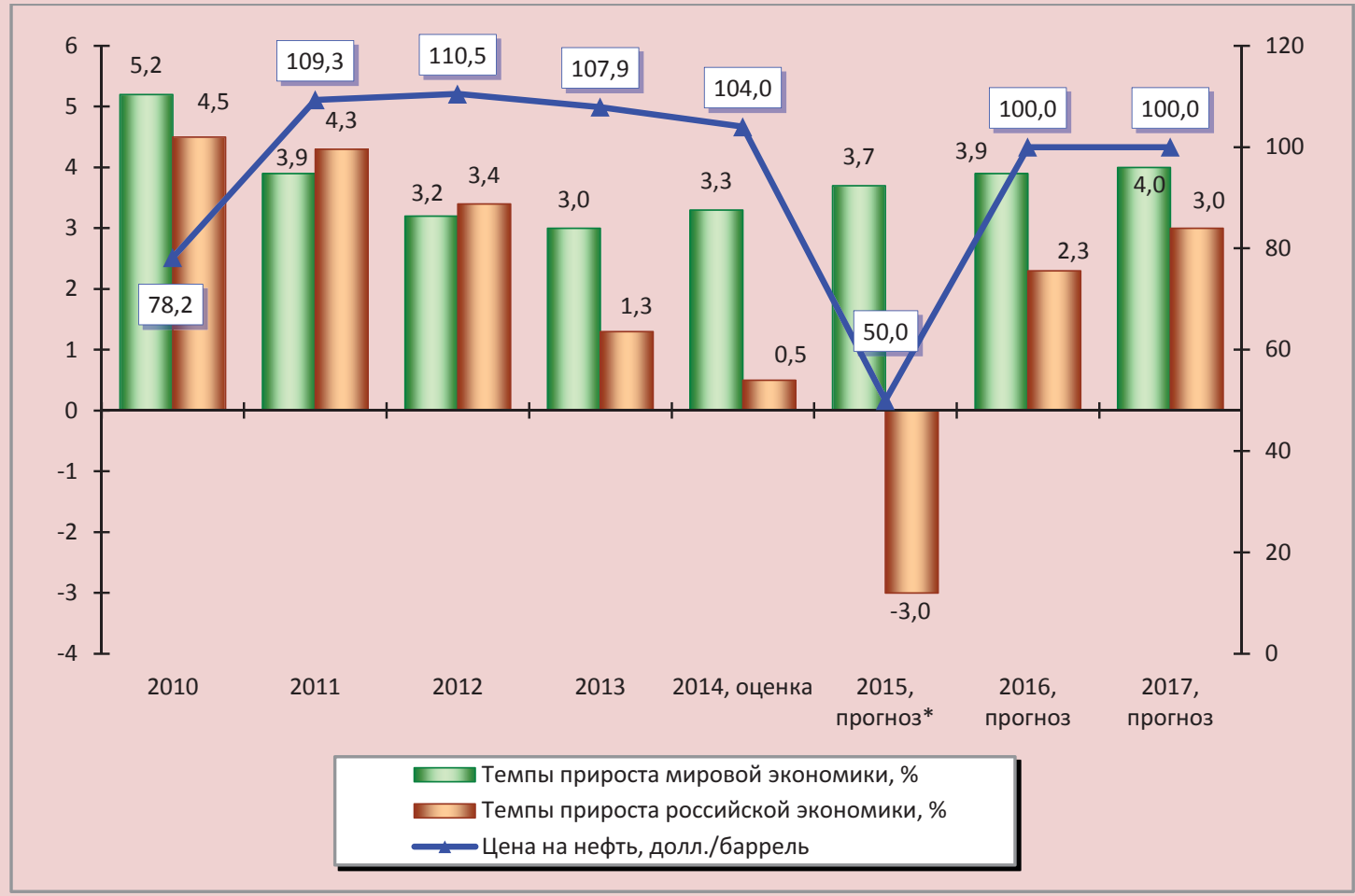

* Данные за 2015 г. представлены с учётом нового прогноза, внесённого Минэкономразвития РФ в Правительство РФ 31.01.2015 г.

Источник: данные прогноза Минэкономразвития РФ от 26.09.2014 г. [13].

Таблица 1. Основные макроэкономические показатели для составления проекта регионального бюджета Вологодской области на 2015-2017 гг., в сопоставимых ценах, \% к предыдущему году

\begin{tabular}{|c|c|c|c|c|c|c|c|c|c|}
\hline \multirow{2}{*}{ Показатели } & \multicolumn{4}{|c|}{ Фактически } & \multirow{2}{*}{$\begin{array}{l}2014, \\
\text { оценка }\end{array}$} & \multicolumn{3}{|c|}{ Прогноз } & \multirow{2}{*}{$\begin{array}{c}2017 \mathrm{k} \\
2014, \%\end{array}$} \\
\hline & 2010 & 2011 & 2012 & 2013 & & 2015 & 2016 & 2017 & \\
\hline ВРП & 105,7 & 106,9 & 104,8 & 100,0 & 100,5 & 102,7 & 102,0 & 101,3 & 106,1 \\
\hline Индекс промышленного производства & 111,1 & 105,6 & 101,3 & 102,3 & 101,3 & 102,6 & 101,7 & 102,7 & 107,2 \\
\hline Инвестиции в основной капитал & 116,1 & 149,4 & 121,2 & 46,2 & 77,7 & 118,0 & 94,7 & 68,7 & 76,8 \\
\hline Оборот розничной торговли & 116,3 & 107,6 & 119,7 & 101,7 & 100,5 & 100,4 & 102,8 & 103,2 & 106,5 \\
\hline $\begin{array}{l}\text { Реальные располагаемые денежные } \\
\text { доходы населения }\end{array}$ & 109,3 & 100,1 & 106,9 & 105,4 & 100,0 & 102,1 & 102,5 & 103,0 & 107,8 \\
\hline
\end{tabular}

Таблица 2. Основные параметры регионального бюджета Вологодской области, млрд. руб.

\begin{tabular}{|l|c|c|c|c|c|c|c|c|c|c|}
\hline \multirow{2}{*}{ Параметры } & \multicolumn{9}{c|}{ Фактически } & \multicolumn{3}{c|}{ Прогноз } \\
\cline { 2 - 13 } & 2008 & 2009 & 2010 & 2011 & 2012 & 2013 & 2014 & 2015 & 2016 & 2017 \\
\hline Доходы, всего & 39,5 & 31,2 & 36,1 & 39,3 & 42,4 & 40,3 & 45,1 & 43,0 & 45,9 & 47,3 \\
\hline В\% К ВРП & 13,4 & 14,6 & 13,7 & 12,2 & 11,9 & 11,3 & 12,5 & 10,8 & 10,8 & 10,7 \\
\hline $\begin{array}{l}\text { Налоговые и неналоговые } \\
\text { (собственные) доходы }\end{array}$ & 34,4 & 19,0 & 25,8 & 28,8 & 31,5 & 30,3 & 35,0 & 35,9 & 40,6 & 41,9 \\
\hline Расходы & 39,1 & 37,7 & 43,1 & 46,5 & 45,2 & 44,2 & 49,0 & 43,0 & 38,0 & 43,5 \\
\hline
\end{tabular}


Год назад, в прогнозе на 2014-2016 гг., ВРП предусматривался в объёме 402,9 млрд. руб. в 2015 г. и 437 млрд. руб. в 2016 г. В прогнозе на 2015-2017 гг. сумма ВРП в 2015 г. снижена на 5,7 млрд. руб., в 2016 г. - на 13,7 млрд. руб.

Таким образом, в 2015-2016 гг. при проектируемом уровне доходов областного бюджета 10,8\% ВРП будет недополучено более 2 млрд. руб.

На сохраняющиеся в экономике региона проблемы указывают также низкие темпы восстановления бюджетных доходов, которые в реальном выражении даже в 2017 г. не выйдут на траекторию их докризисного объёма (рис. 2).

Ключевым фактором снижения самообеспеченности Вологодской области начиная с 2009 г. стало изменение структуры доходной части бюджета, связанное с рез- ким падением поступлений налога на прибыль от крупнейшей корпорации чёрной металлургии - публичного акционерного общества «Северсталь» (ПАО «Северсталь»), обеспечивавшей до 2009 г. более половины платежей по данному доходному источнику. В прогнозном периоде это предприятие так и не вернёт себе статус главного катализатора сборов налога на прибыль (рис. 3).

Более того, обращает на себя внимание тот факт, что металлургическая промышленность не рассматривается правительством области в качестве фактора влияния на прибыль, поскольку прогноз прибыли на 2015-2017 гг. не включает показатели этой отрасли. Между тем ещё в 2012 г. металлурги обеспечивали $36 \%$ совокупного объёма прибыли хозяйствующих субъектов (puc. 4).

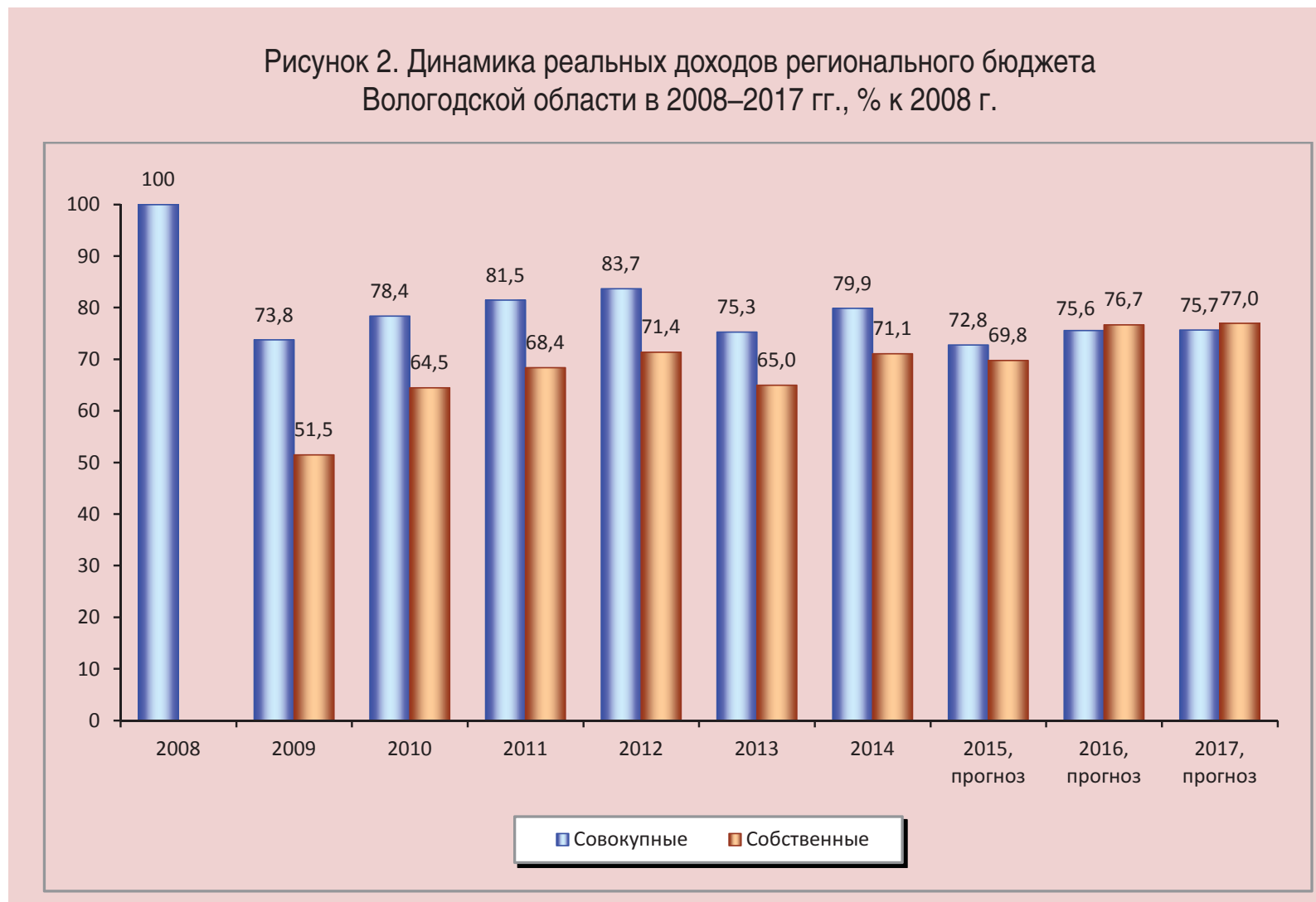

Источники: данные Федерального казначейства [15]; Департамента фринансов Вологодской области [12]; расчёты автора. 
Рисунок 3. Динамика поступлений налога на прибыль в региональный бюджет Вологодской области в 2008-2017 гг., млрд. руб.

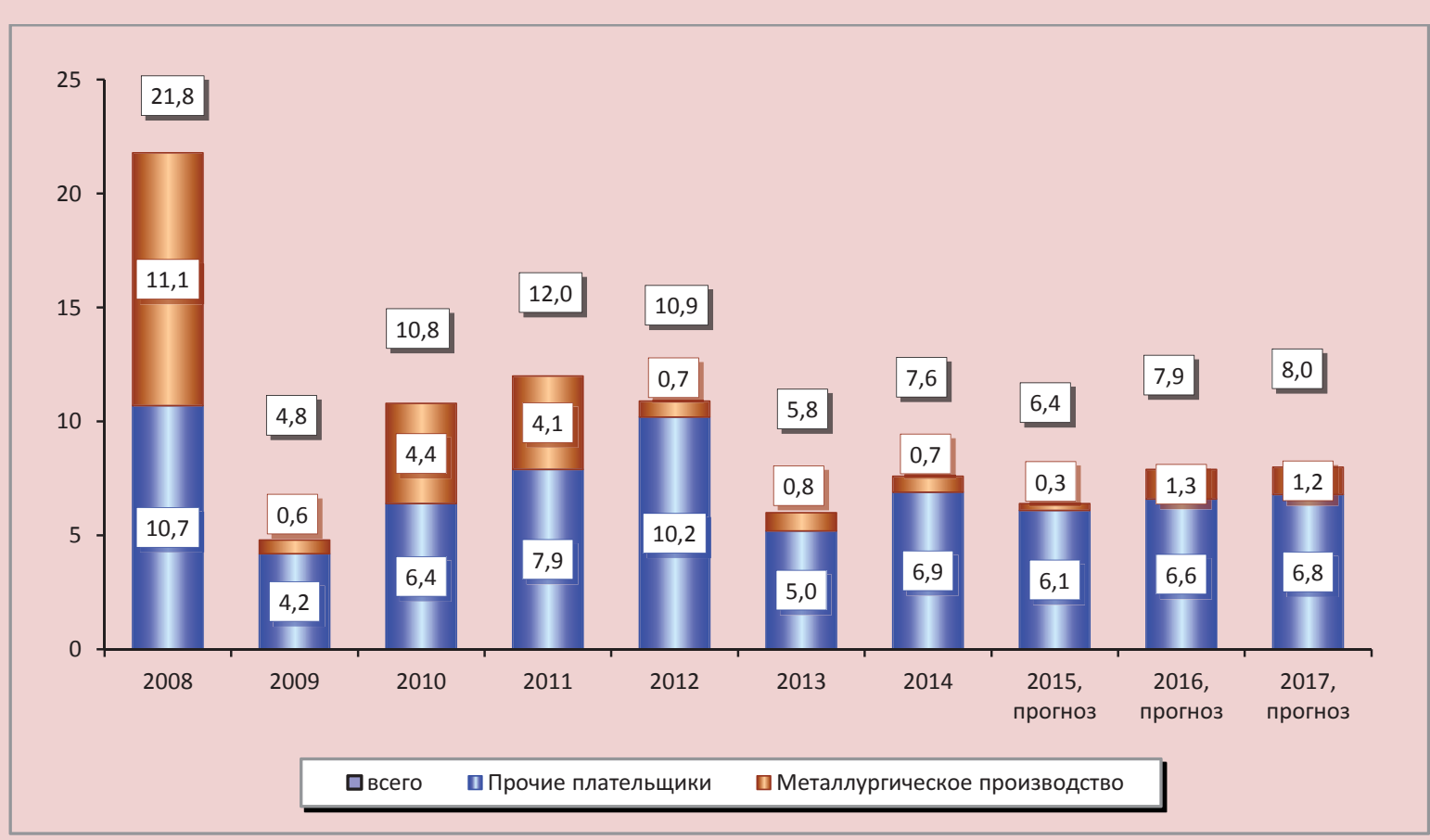

Источники: данные ФНС; [16]; Департамента фринансов Вологодской области; расчёты автора.

Рисунок 4. Динамика прибыли до налогообложения организаций Вологодской области в 2008-2017 гг., млрд. руб.

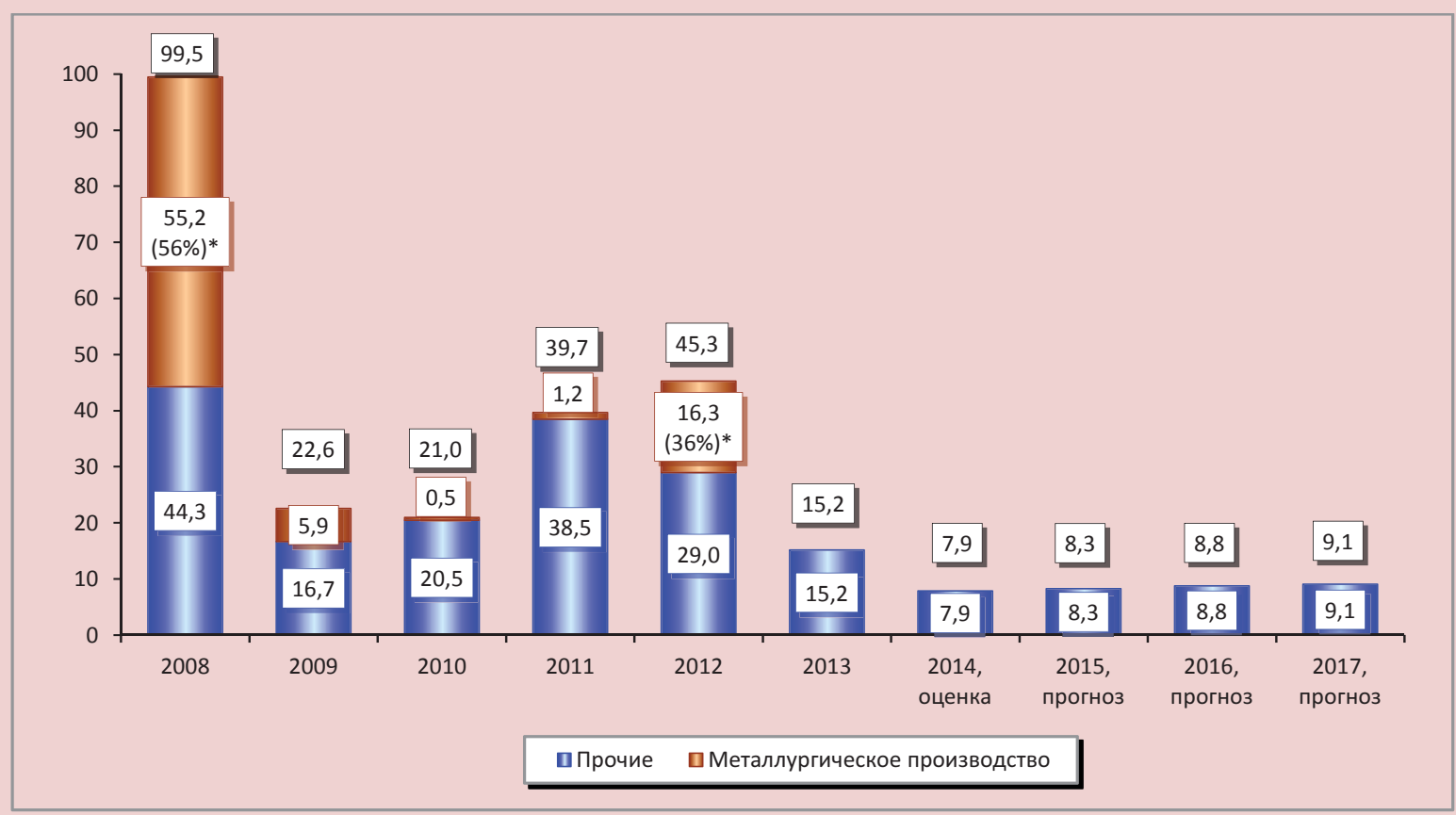

* В скобках указана доля металлургического производства в общем объёме прибыли по экономике. Источники: данные Департамента финансов Вологодской области; расчёты автора. 
Необходимо также отметить, что рост прибыли по экономике Вологодской области в 2015-2017 гг. составит 15\% и будет опережать рост ВРП (6\%). При этом инвестиции в основной капитал, как уже было сказано, сократятся на 23\%. Это значит, что прибыль хозяйствующих субъектов не вкладывается в программы модернизации производства, а становится источником оттока капитала ${ }^{3}$.

Кризисные последствия кардинально изменили структуру собственных доходов областного бюджета, что выразилось в сильнейшем падении удельного веса налога на прибыль. Причём в посткризисный период поступления никаких других налогов не смогли компенсировать потери налога на прибыль.

В предстоящем бюджетном цикле основную роль в формировании собственных доходов региональной казны будут играть налог на доходы физических лиц (НДФЛ) и налоги на имущество - их доля составит соответственно 34 и 26\%. Удельный вес налога на прибыль окажется на уровне 19\%, что меньше, чем в кризисном 2009 году (рис. 5).

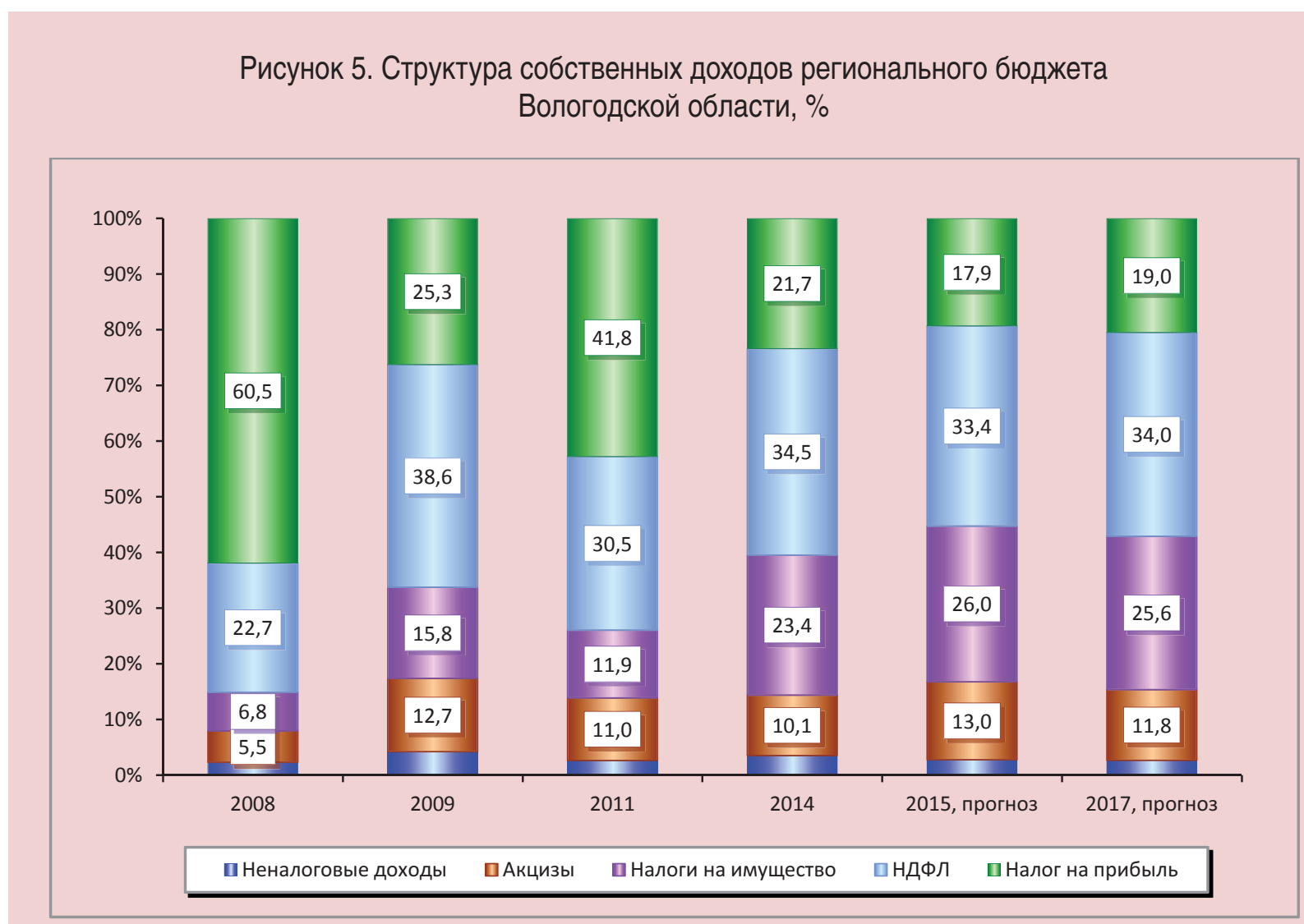

Источники: данные Федерального казначейства; Департамента финансов Вологодской области; расчёты автора.

3 К сожалению, банковская статистика не содержит информацию о вывозе капитала в региональном разрезе. По данным Центробанка, общий отток капитала из России за 2014 г. стал самым масштабным и достиг 151,5 млрд. долл. (для сравнения: в 2008 г. - 133,6 млрд. долл., в 2013 г. - 61 млрд. долл.). 
Замедление темпов роста заработной платы не позволит существенно увеличить объём поступлений НДФЛ. В 20152017 гг. он будет прирастать ежегодно на 0,5 млрд. руб., что в два раза меньше, чем в 2012-2014 гг. (табл. 3).

В связи с серьёзным снижением самообеспеченности региональный бюджет становится всё более зависимым от финансовой поддержки из федерального бюджета в форме межбюджетных трансфертов и кредитов. За 2008-2014 гг. её объём вырос в четыре раза - с 5 до 19 млрд. руб. (рuc. 6).

Судя по данным рисунка, приоритетом межбюджетной политики начиная с 2014 г. становится замещение трансфертного финансирования долговым. В 2015-2017 гг. плановый объём бюджетных кредитов почти в два раза превысит объём трансфертной помощи.

Существенное снижение межбюджетных трансфертов Вологодской области станет одним из главных факторов сокра- щения реальных доходов регионального бюджета в предстоящей трёхлетке. В результате будет увеличиваться разрыв в обеспеченности населения бюджетными доходами по сравнению со среднероссийским уровнем (рис. 7).

В 2015-2017 гг. Правительство Вологодской области поставило амбициозную задачу достижения сбалансированности регионального бюджета ${ }^{4}$ (рис. 8).

Поставленная задача будет решаться за счёт сокращения расходов, причём по всем функциональным статьям. В 2017 г. расходная часть бюджета уменьшится в текущих ценах на 5,6 млрд. руб., а с учётом инфляции - на 11,4 млрд. руб., или на 23\% к уровню 2014 г. (табл. 4).

Масштабное снижение финансового обеспечения ожидается по жилищно-коммунальному хозяйству - $63 \%$, что определяется уменьшением расходов на бюджетные инвестиции и капитальный ремонт объектов государственной и муниципальной собственности.

Таблица 3. Поступление НДФЛ в региональный бюджет Вологодской области и заработная плата в 2012-2017 гг.

\begin{tabular}{|c|c|c|c|c|c|c|c|c|}
\hline \multirow{2}{*}{ Показатели } & \multirow{2}{*}{$\begin{array}{l}2012, \\
\text { факт }\end{array}$} & \multirow{2}{*}{$\begin{array}{l}2013, \\
\text { факт }\end{array}$} & \multirow{2}{*}{$\begin{array}{l}2014, \\
\text { фракт }\end{array}$} & \multirow{2}{*}{$\begin{array}{l}\text { В среднем за } \\
\text { 2012-2014 }\end{array}$} & \multicolumn{3}{|c|}{ Прогноз } & \multirow{2}{*}{$\begin{array}{c}\text { В среднем за } \\
2015-2017\end{array}$} \\
\hline & & & & & 2015 & 2016 & 2017 & \\
\hline НДФЛ, млрд. руб. & 9,6 & 10,5 & 12,1 & 10,7 & 12,0 & 13,4 & 14,3 & 13,2 \\
\hline \multicolumn{9}{|l|}{ К предыдущему году } \\
\hline - млрд. руб. & 0,8 & 0,9 & 1,6 & 1,1 & $-0,9$ & 1,4 & 0,9 & 0,5 \\
\hline$-\%$ & 109,5 & 109,3 & 114,8 & 111,2 & 92,8 & 111,5 & 106,8 & 103,7 \\
\hline $\begin{array}{l}\text { Среднемесячная номинальная } \\
\text { заработная плата, руб. }\end{array}$ & 22649 & 25127 & 26643 & 24806 & 27997 & 29703 & 31713 & 29804 \\
\hline Темп роста, \% & 111,8 & 110,9 & 106,0 & 109,6 & 105,1 & 106,1 & 106,8 & 106,0 \\
\hline $\begin{array}{l}\text { Реальная заработная плата, \% к } \\
\text { предыдущему году }\end{array}$ & 106,9 & 104,4 & 98,7 & 103,3 & 98,5 & 101,6 & 102,4 & 100,8 \\
\hline
\end{tabular}

4 Основой послужило соглашение Вологодской области с Минфином РФ о предоставлении бюджетного кредита на замещение коммерческих кредитов в сумме 6 млрд. руб. В соответствии с условиями соглашения областной бюджет на 2015-2017 гг. должен быть сформирован без дефицита, а объём рыночных заимствований к 1 января 2017 г. снижен до $50 \%$ от объёма собственных доходов бюджета. 
Рисунок 6. Динамика финансовой помощи из федерального бюджета региональному бюджету Вологодской области в 2008-2017 гг., млрд. руб.

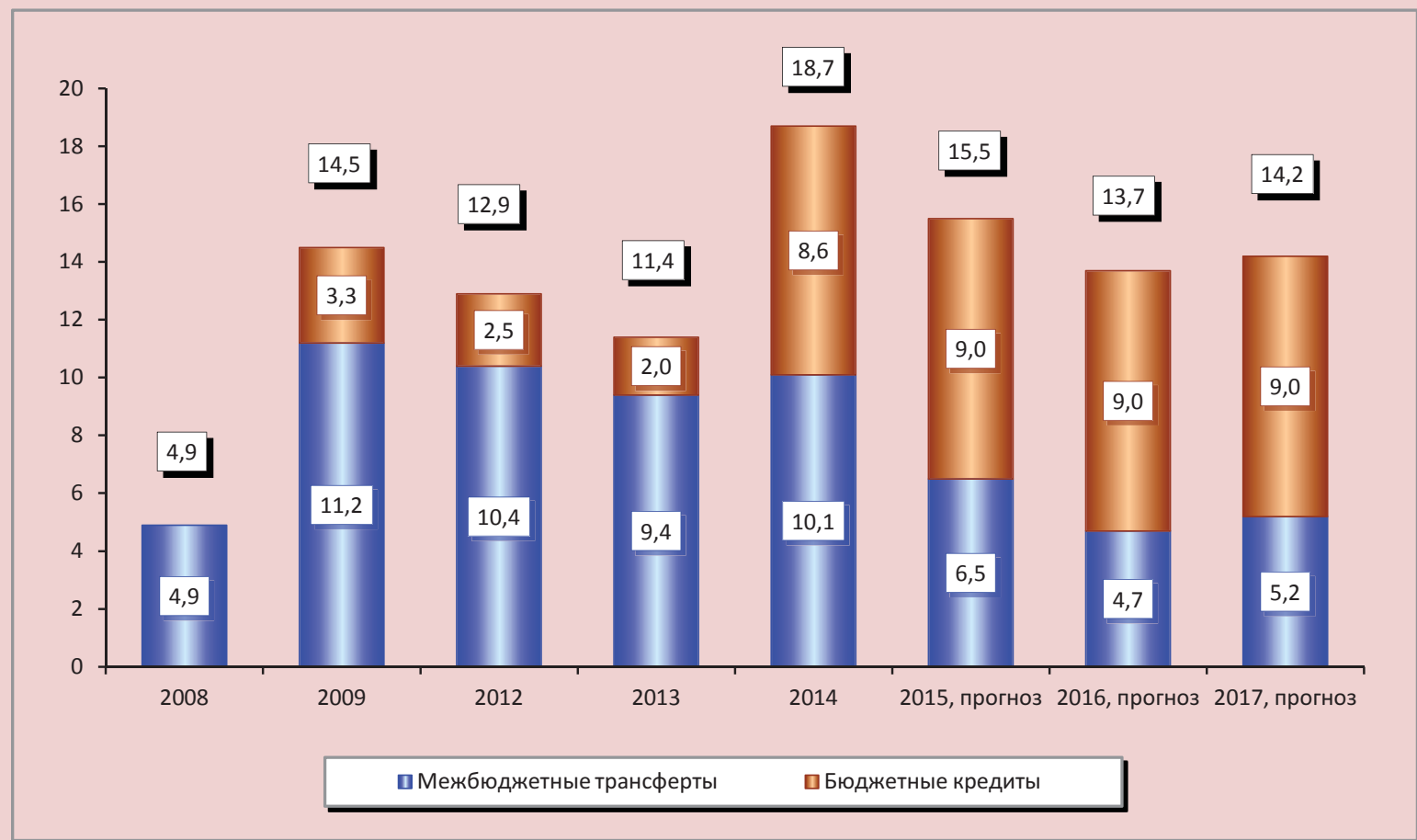

Источники: данные Федерального казначейства; Департамента фринансов Вологодской области; расчёты автора.

Рисунок 7. Обеспеченность населения Вологодской области бюджетными доходами в 2012-2017 гг.

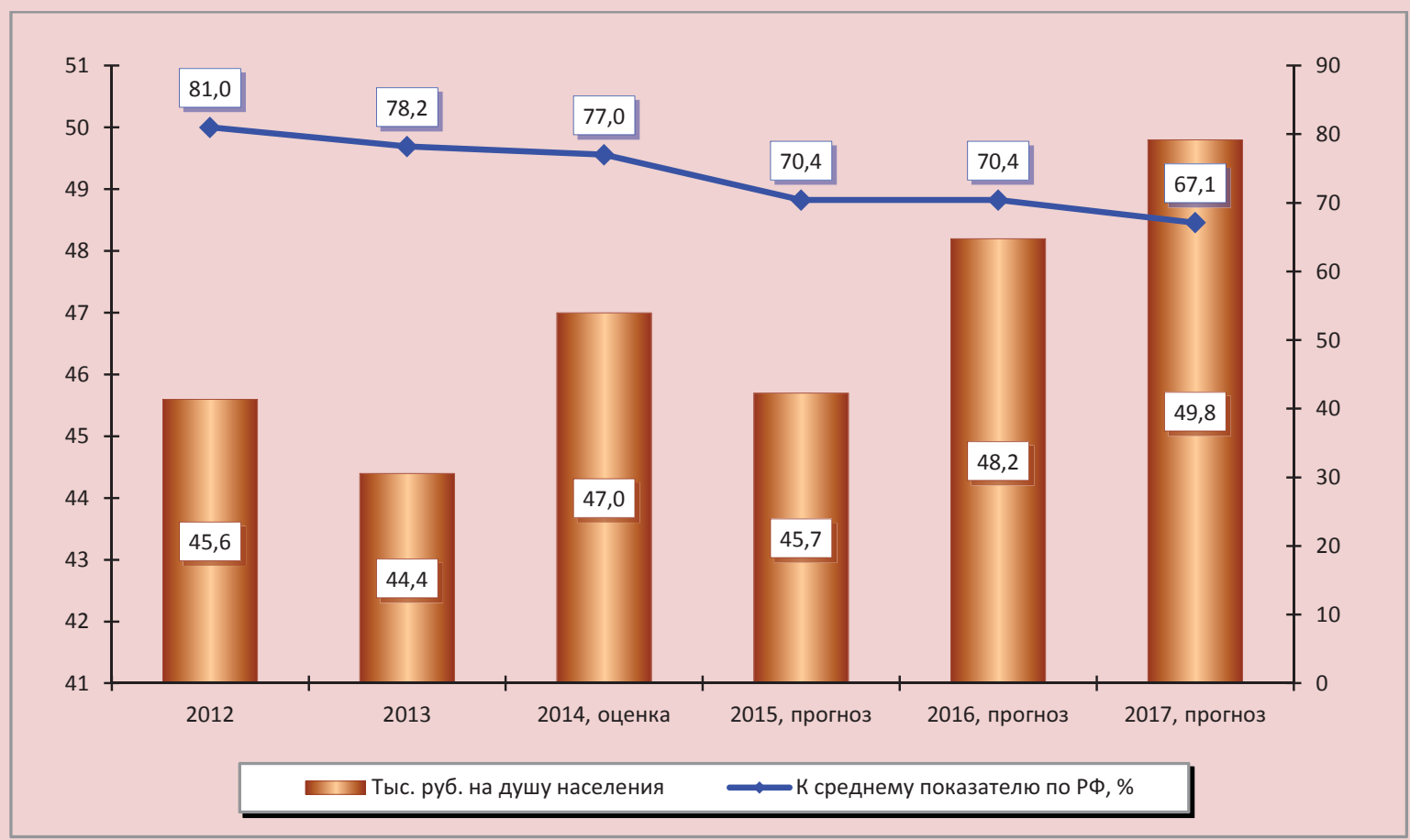

* Данные по консолидированному бюджету Вологодской области.

Источник: расчёт автора по данным Федерального казначейства; Росстата; Минфина РФ; Департамента финансов Вологодской области. 


\section{Рисунок 8. Динамика результатов исполнения регионального бюджета} Вологодской области в 2008-2017 гг., млрд. руб.

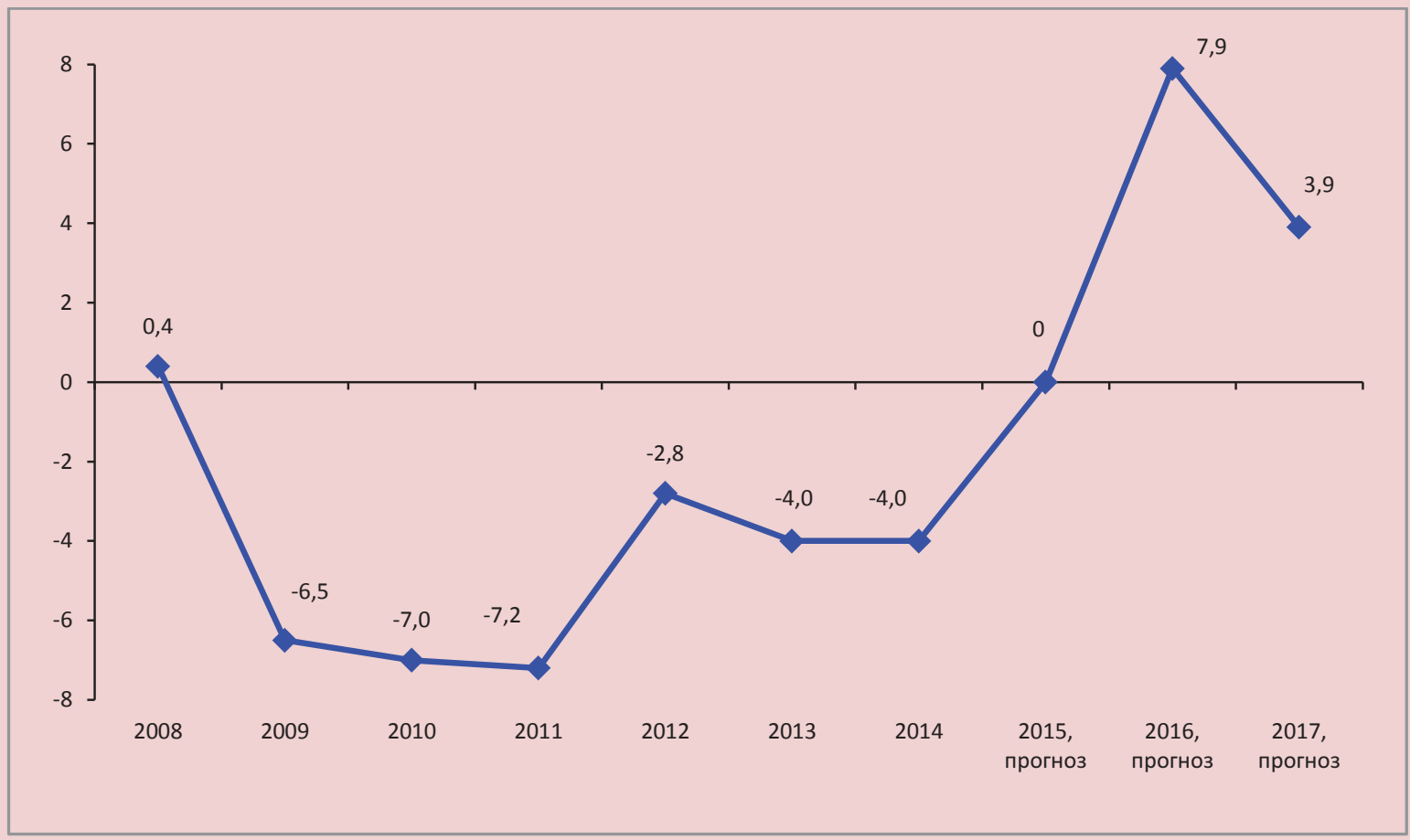

Источники: данные Федерального казначейства; Департамента фринансов Вологодской области.

Таблица 4. Динамика расходов регионального бюджета

Вологодской области в 2014-2017 гг., млн. руб.

\begin{tabular}{|c|c|c|c|c|c|c|c|c|c|}
\hline \multirow{3}{*}{ Расходы } & \multirow{3}{*}{$\begin{array}{c}2014 \\
\begin{array}{c}\text { Номи- } \\
\text { нальные }\end{array}\end{array}$} & \multicolumn{6}{|c|}{ Прогноз } & \multirow{2}{*}{\multicolumn{2}{|c|}{2017 к 2014, \% }} \\
\hline & & \multicolumn{2}{|c|}{2015} & \multicolumn{2}{|c|}{2016} & \multicolumn{2}{|c|}{2017} & & \\
\hline & & $\begin{array}{c}\text { Номи- } \\
\text { нальные }\end{array}$ & $\begin{array}{l}\text { Реаль- } \\
\text { ные }^{*}\end{array}$ & $\begin{array}{c}\text { Номи- } \\
\text { нальные }\end{array}$ & $\begin{array}{l}\text { Реаль- } \\
\text { ные }^{*}\end{array}$ & $\begin{array}{c}\text { Номи- } \\
\text { нальные }\end{array}$ & $\begin{array}{l}\text { Реаль- } \\
\text { ные }^{*}\end{array}$ & $\begin{array}{c}\text { Номи- } \\
\text { нальные }\end{array}$ & $\begin{array}{l}\text { Реаль- } \\
\text { ные }^{*}\end{array}$ \\
\hline Расходы, всего & 49046 & 43005 & 40305 & 38043 & 34242 & 43470 & 37669 & 88,6 & 76,8 \\
\hline $\begin{array}{l}\text { Общегосударственные } \\
\text { расходы }\end{array}$ & 2330 & 2396 & 2246 & 1845 & 1660 & 1892 & 1640 & 81,2 & 70,4 \\
\hline Национальная экономика & 9020 & 6437 & 6033 & 5540 & 4987 & 6549 & 5675 & 72,6 & 62,9 \\
\hline - сельское хозяйство & 2628 & 1232 & 1155 & 744 & 670 & 924 & 801 & 35,2 & 30,5 \\
\hline KKX & 947 & 863 & 809 & 762 & 685 & 404 & 350 & 42,7 & 37,0 \\
\hline Социальная сфера & 32789 & 29831 & 27957 & 26238 & 23617 & 29697 & 25734 & 90,6 & 78,5 \\
\hline - образование & 13381 & 10716 & 10043 & 9945 & 8951 & 11353 & 9838 & 84,8 & 73,5 \\
\hline - культура & 767 & 517 & 485 & 465 & 418 & 498 & 432 & 65,0 & 56,3 \\
\hline - здравоохранение & 7717 & 7804 & 7314 & 6604 & 5945 & 7433 & 6441 & 96,3 & 83,5 \\
\hline - социальная политика & 10661 & 10590 & 9925 & 9131 & 8219 & 10328 & 8949 & 96,9 & 83,9 \\
\hline - фризкультура и спорт & 263 & 203 & 191 & 93 & 84 & 85 & 73 & 32,1 & 27,7 \\
\hline
\end{tabular}


На 37\% лишается прежней поддержки национальная экономика. В частности, расходы на сельское хозяйство в 2017 г. составят всего $30 \%$ от уровня 2014 г., что будет ограничивать возможности развития импортозамещения.

Перспективы бюджетирования социальной сферы выглядят не менее удручающими: расходы на образование снижаются на 27\%, здравоохранение и социальную политику - на $16 \%$, культурную деятельность - на 44\%, физкультуру и спорт - на $72 \%$.

Необходимость достижения баланса и сверхсоциальная структура расходов на- глядно характеризуют ещё одну проблему регионального бюджета, связанную с прогрессирующим уменьшением капиталовложений. Объём бюджетных инвестиций за три года сократится на 2,5 млрд. руб., или в четыре раза по сравнению с 2014 г. (рис. 9).

Создаётся впечатление, что правительство области сделало выбор в пользу окончательной оптимизации капитальных расходов ${ }^{5}$.

Несмотря на беспрецедентную оптимизацию, достижение бездефицитности региональной казны, на наш взгляд, представляется маловероятным.

Рисунок 9. Динамика капитальных вложений регионального бюджета

Вологодской области в 2008-2017 гг., в ценах 2008 г.

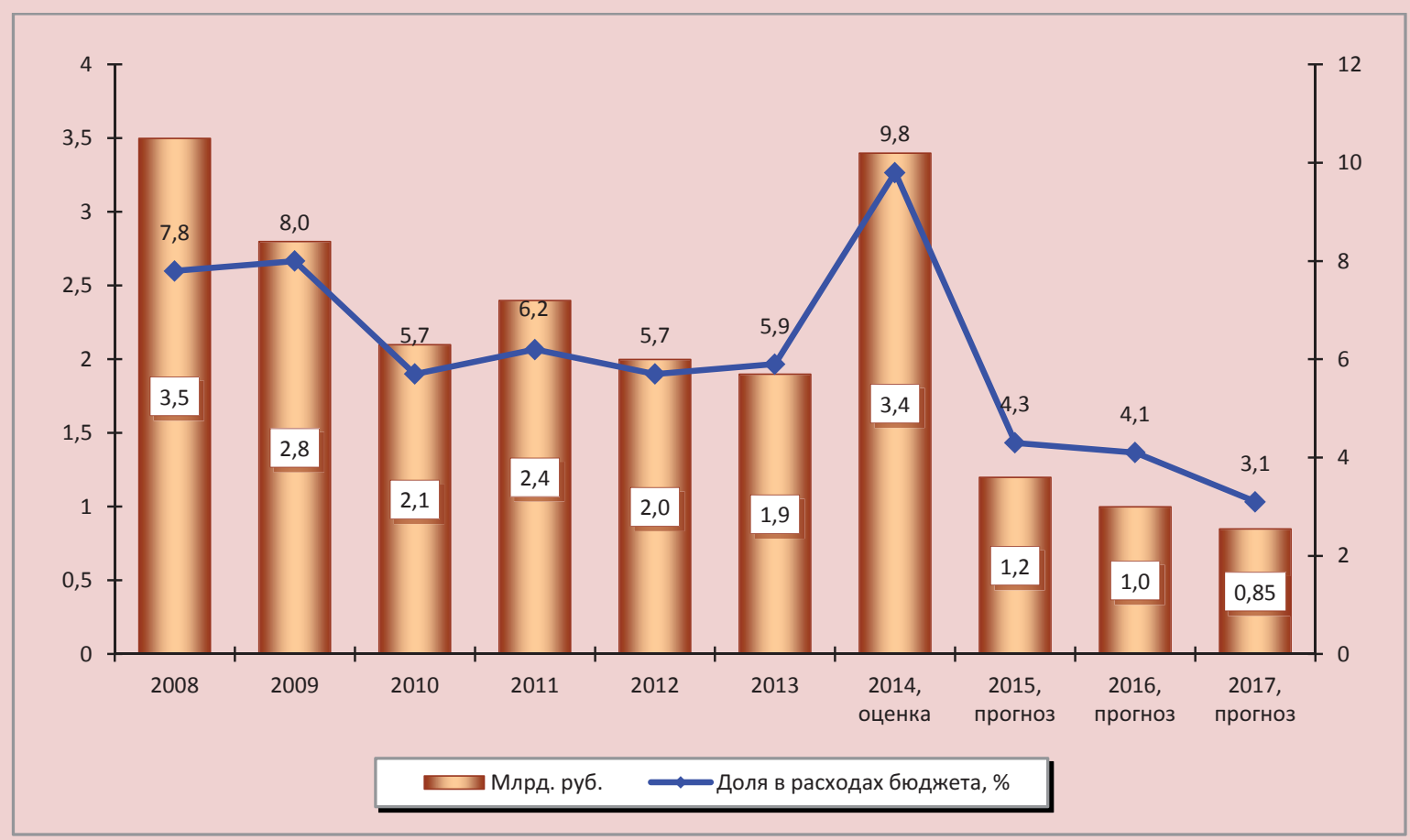

Источники: данные Федерального казначейства; Департамента финансов Вологодской области; расчёты автора.

По удельному весу средств, направляемых на формирование бюджета развития, Вологодская область в 2013 г. занимала 7-е место в СЗФО. При среднем уровне по округу, составившем 10,3\%, на инвестиции было потрачено 5,9\% расходов регионального бюджета. Даже в высокодотационных Новгородской и Псковской областях данный показатель составил 10,7 и $6,5 \%$ соответственно. 
Во-первых, практика формирования профицитного бюджета существует уже несколько лет. Реальный же бюджетный процесс оказывается далёким от сценарных условий и вынуждает прибегать к многократным корректировкам результатов исполнения бюджета.

Так, бюджеты и на 2014-й, и на 2015 год первоначально были объявлены профицитными, а при формировании основных характеристик следующего бюджетного цикла - дефицитными (табл. 5).

Во-вторых, реализация мероприятий в рамках указов Президента РФ от 7 мая 2012 г., ставших, по сути, нефинансируемыми социальными мандатами для регионов, потребует более 16 млрд. руб., в то время как реальные средства на эти цели составляют 8,7 млрд. руб., то есть половину необходимого. Особенно остро дефицит финансовых ресурсов будет ощущаться в 2015 г. (табл. 6).
В случае отсутствия должной поддержки из федерального центра исполнение указов, как показала практика предыдущих лет, будет осуществляться посредством ликвидации бюджетной сети и сокращения численности работников ${ }^{6}$.

В-третьих, в результате сложившегося дисбаланса межбюджетных отношений, характеризующегося увеличением количества переданных регионам полномочий Федерации ${ }^{7}$ с одновременным сокращением безвозмездной финансовой помощи из федерального бюджета, средний уровень покрытия расходов областного бюджета за счёт собственных доходов в 2015-2017 гг. составит $88 \%$.

В-четвёртых, сохраняется высокая зависимость местных бюджетов от трансфертов из областного бюджета, что является одной из главных причин возникновения его дефицита. С введением в 2006 г. новой системы местного само-

Таблица 5. Изменение прогнозных параметров результатов исполнения регионального бюджета Вологодской области, млн. руб.

\begin{tabular}{|l|c|c|c|}
\hline \multicolumn{1}{|c|}{ Закон } & 2014 & 2015 & 2016 \\
\hline Закон о бюджете на 2012-2014 гг. & 5920,1 & & $-2014,8$ \\
\hline Закон о бюджете на 2013-2015 гг. & 3215,5 & 5345,4 & $-1486,0$ \\
\hline Закон о бюджете на 2014-2016 гг. & $-3212,1$ & $-2014,8$ & $+7898,3$ \\
\hline Закон о бюджете на 2015-2017 гг. & & 0 & \\
\hline
\end{tabular}

Таблица 6. Прогноз расходов регионального бюджета Вологодской области на реализацию указов Президента РФ в 2015-2017 гг., млн. руб.

\begin{tabular}{|l|c|c|c|c|}
\hline \multicolumn{1}{|c|}{ Показатели } & 2015 & 2016 & 2017 & Всего \\
\hline Потребность в средствах & 5400,8 & 5304,1 & 5663,2 & 16368,1 \\
\hline Предусмотрено в бюджете & 1730,3 & 3068,3 & 3913,7 & 8712,3 \\
\hline Недостаток средств & & & & 7655,8 \\
\hline - млн. руб. & 3670,5 & 2235,8 & 1749,5 & 53,2 \\
\hline - \% & 32,0 & 57,8 & 69,1 & \\
\hline \multicolumn{2}{|l|}{} \\
Источник: данные Департамента фринансов Вологодской области. \\
\hline
\end{tabular}

6 По данным Департамента финансов, за 2012-2013 гг. в Вологодской области закрыто 98 учреждений образования и культуры, сокращено 1607 работающих.

С 2004 по 2013 год количество федеральных полномочий, переданных на региональный уровень, увеличилось почти в три раза. При этом количество налогов, закреплённых за бюджетами регионов, сократилось с семи до трёх. 
управления доля межбюджетных трансфертов муниципалитетам в расходах областного бюджета стабильно составляет более $40 \%$.

В-пятых, в 2015-2017 гг. плановые расходы на возврат коммерческих и бюджетных кредитов, привлечённых в предыдущие годы для финансирования бюджетного дефицита, достигнут 53,7 млрд. руб., что кардинально изменит фактические результаты исполнения бюджета ${ }^{8}$ (табл. 7).

По нашим расчётам, в 2017 г. реальный дефицит областного бюджета достигнет 19 млрд. руб., на его погашение предстоит направить почти половину собственных доходных источников. В условиях огра- ниченной самообеспеченности бюджета финансирование дефицита скорее всего вызовет необходимость новых заимствований или секвестра.

В-шестых, достижение сбалансированности регионального бюджета нереалистично в условиях высокой закредитованности.

Формируя бездефицитный бюджет, правительство области рассчитывает снизить острую долговую нагрузку. Действительно, в прогнозном периоде абсолютный объём государственного долга уменьшится с 35 млрд. руб. в 2014 г. до 23,6 млрд. руб. в 2017 г., но будет оставаться существенным, соответствуя $57 \%$ объёма собственных доходов регионального бюджета (табл. 8).

Таблица 7. Реальные результаты исполнения регионального бюджета Вологодской области в 2014-2017 гг., млн. руб.

\begin{tabular}{|l|c|c|c|c|}
\hline \multicolumn{1}{|c|}{ Показатели } & \multirow{2}{*}{2014} & \multicolumn{3}{c|}{ Прогно3 } \\
\cline { 3 - 5 } & & 2015 & 2016 & 2017 \\
\hline Десрицит (-), просрицит без расходов на возврат кредитов & -3960 & 0 & 7898 & 3856 \\
\hline К собственным доходам бюджета, \% & $-11,3$ & 0 & 19,4 & 9,2 \\
\hline Расходы на возврат кредитов * & 24471 & 11563 & 19092 & 23016 \\
\hline Реальный десицит (-), просрицит & -28431 & -11563 & -11194 & -19160 \\
\hline К собственным доходам бюджета, \% & $-81,3$ & $-32,2$ & $-27,5$ & $-45,7$ \\
\hline * Утверждено в законе об областном бюджете на 2014-2016 гг. & & & \\
\hline
\end{tabular}

Таблица 8. Динамика и структура государственного долга

Вологодской области в 2014-2017 гг., млрд. руб.

\begin{tabular}{|c|c|c|c|c|c|c|c|c|c|}
\hline \multirow{2}{*}{ Показатели } & \multicolumn{2}{|c|}{ 2014, фракт } & \multicolumn{2}{|c|}{ 2015, прогно3 } & \multicolumn{2}{|c|}{ 2016, прогноз } & \multicolumn{2}{|c|}{ 2017, прогно3 } & \multirow{2}{*}{$\begin{array}{r}2017 \mathrm{k} \\
2014, \%\end{array}$} \\
\hline & Млрд. руб. & $\%$ & Млрд. руб. & $\%$ & Млрд. руб. & $\%$ & Млрд. руб. & $\%$ & \\
\hline Госдолг, всего & 34,9 & 100,0 & 35,2 & 100,0 & 27,3 & 100,0 & 23,6 & 100,0 & 67,6 \\
\hline Банковские кредиты & 14,0 & 40,1 & 20,6 & 58,6 & 19,1 & 70,0 & 20,6 & 87,4 & 147,1 \\
\hline Бюджетные кредиты & 12,6 & 36,1 & 8,5 & 24,2 & 4,2 & 15,4 & 0 & 0 & 0 \\
\hline Госгарантии & 3,4 & 9,6 & 3,3 & 9,4 & 3,1 & 11,4 & 3,0 & 12,6 & 88,2 \\
\hline Ценные бумаги & 4,9 & 14,1 & 2,8 & 7,8 & 0,9 & 3,2 & 0 & 0 & 0 \\
\hline Долговая нагрузка, \%* & \multicolumn{2}{|c|}{99,8} & \multicolumn{2}{|c|}{99,3} & \multicolumn{2}{|c|}{68,3} & \multicolumn{2}{|c|}{57,2} & $-43,3$ \\
\hline
\end{tabular}

8 Несмотря на неоднократные обращения глав субъектов РФ (в частности, губернатора Вологодской области О.А. Кувшинникова) в Минфин РФ с просьбой о внесении изменений в порядок учёта расходов на возврат кредитов, данные расходы включаются не в расходную часть бюджета, а в состав источников финансирования дефицита, что приводит к искажению его фактического размера. 
Уровень коммерческой задолженности в структуре долговых обязательств будет неуклонно расти и составит к концу бюджетного цикла $87,4 \%$, создавая тем самым дополнительные риски долговой устойчивости бюджета. Более того, после существенного снижения привлечённых займов в 2015-2016 гг. правительство области в 2017 г. планирует набирать новые банковские кредиты, что повлечёт за собой возобновление роста расходов на их обслуживание (рис. 10).

Если суммировать расходы на возврат и обслуживание кредитов, то их объём превысит другие важнейшие направления финансирования регионального бюджета. По сути, данные расходы стали приоритетными (рис. 11).

Совершенно очевидно, что в ближайшей перспективе региональным властям не удастся кардинально поменять ситуацию в сфере долговой политики, а от- влечение бюджетных средств на возврат заимствований и процентные платежи будет усиливать риски исполнения первоочередных расходных обязательств.

Можно и дальше перечислять изъяны очередного трёхлетнего бюджета, но в конечном итоге, по нашему мнению, они предопределяются дефектами проводимой в стране налогово-бюджетной политики, которая, вместо того чтобы служить важнейшим инструментом управления территориальным развитием, всё глубже погружает российские регионы в бюджетный кризис.

Чем другим можно объяснить, что только 10 субъектов РФ являются самодостаточными (не получающими дотаций на выравнивание бюджетной обеспеченности), что дефицит региональных бюджетов за 2013-2014 гг. достиг исторического максимума, в несколько раз превысив плановые значения [7], и большинство

Рисунок 10. Динамика привлечённых коммерческих кредитов и процентных расходов регионального бюджета Вологодской области в 2009-2017 гг., млрд. руб.

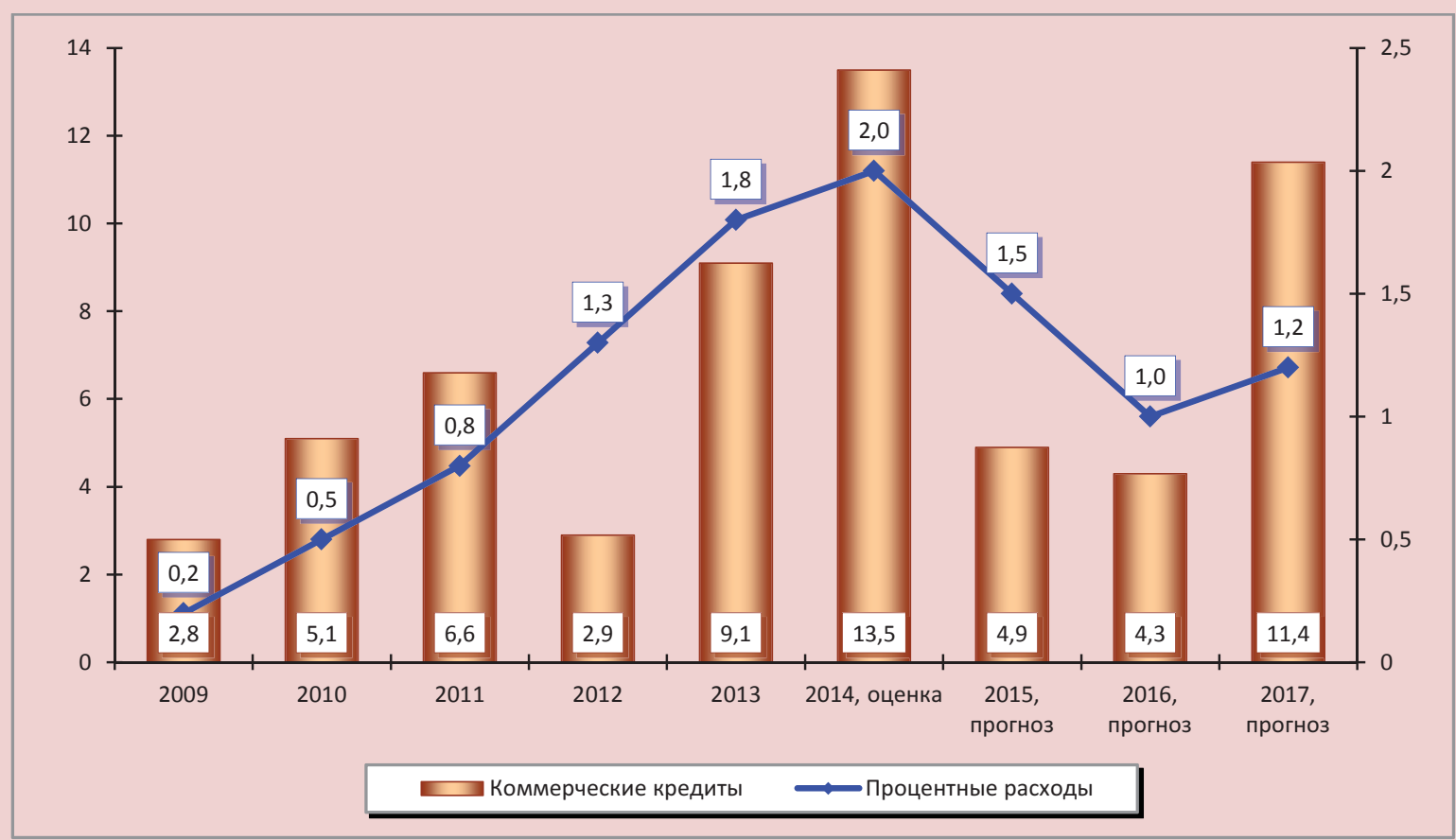

Источники: данные Федерального казначейства; Департамента фринансов Вологодской области; расчёты автора. 
Рисунок 11. Основные функциональные расходы и расходы на возврат кредитов регионального бюджета Вологодской области в 2013-2017 гг., млрд. руб.

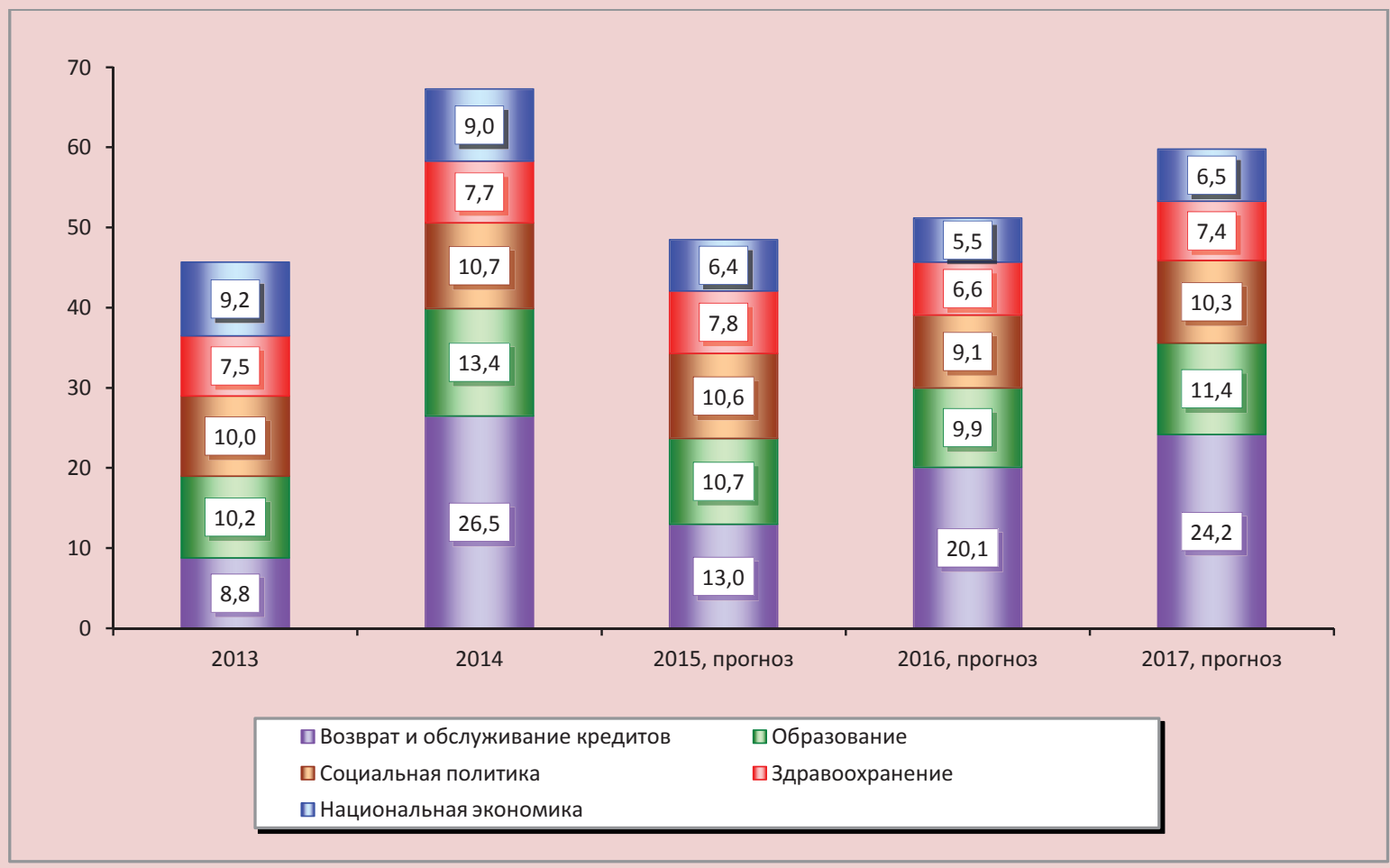

Источник: расчёт автора по данным Департамента финансов Вологодской области.

регионов балансируют на грани банкротства, продолжая заимствовать средства не на развитие, а на обеспечение текущих расходов? С января по ноябрь 2014 г. закредитованность субъектов РФ выросла на 75\%, впервые превысив триллион рублей (рис. 12). Привлечённые кредиты уступают по объёму лишь расходам региональных бюджетов на образование и социальную политику.

Нормативы зачисления доходов в территориальные бюджеты, установленные Бюджетным кодексом РФ, не обеспечивают реализацию закреплённых за регионами полномочий. При этом, решая проблему дефицита федерального бюджета за счёт перекладывания государственных расходов на нижестоящие уровни, центральное правительство вынуждает региональные власти изначально формировать свои бюд- жеты с предельными значениями долговых обязательств. К примеру, в 2015 г. долговая нагрузка регионов Северо-Запада РФ, за исключением г. Санкт-Петербурга и Ленинградской области, приблизится к критическому уровню, а в Республике Карелия превысит его (табл. 9).

Острый долговой кризис большинства субъектов РФ во многом обусловлен запоздалой реакцией центральных властей на нарастающие риски. Только в июле 2014 г. Правительством РФ было принято решение о трансформации коммерческих кредитов в бюджетные, выдаваемые по низкой процентной ставке 9 .

В 2014 г. средние ставки по коммерческим кредитам, привлечённым субъектами РФ, составляли $10,8-13,5 \%$, по бюджетным кредитам - 1/4 ставки рефинансирования Центробанка (для финансово слабых регионов, в том числе для Вологодской области, бюджетные кредиты на замещение банковских выдаются по ставке $0,1 \%$ годовых). 
Рисунок 12. Динамика кредитов, привлечённых субъектами РФ в 2008-2014 гг.

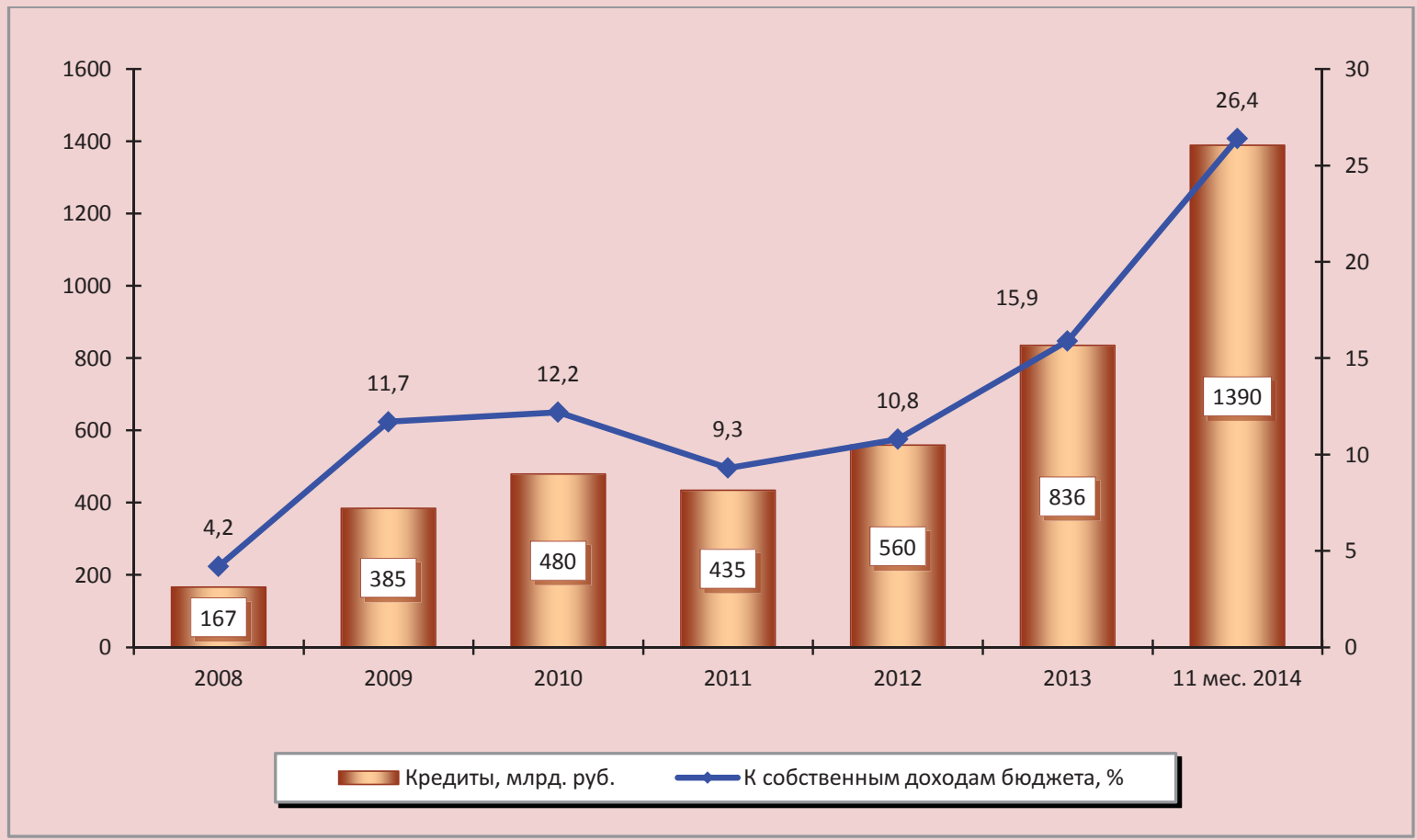

Источники: данные Федерального казначейства; расчёты автора.

Таблица 9. Верхний предел государственного долга региональных бюджетов субъектов СЗФО в 2014-2015 гг.

\begin{tabular}{|l|c|c|c|c|}
\hline \multirow{2}{*}{ Субъект } & \multicolumn{2}{|c|}{ Утверждено на 2014 г. } & \multicolumn{2}{c|}{ Утверждено на 2015 г. } \\
\cline { 2 - 5 } & Млрд. руб. & $\begin{array}{c}\text { К собственным доходам } \\
\text { бюджета, \% }\end{array}$ & Млрд. руб. & $\begin{array}{c}\text { К собственным доходам } \\
\text { бюджета, \% }\end{array}$ \\
\hline г. Санкт-Петербург & 14,6 & 3,8 & 79,6 & 20,0 \\
\hline Ленинградская область & 22,0 & 33,8 & 22,9 & 32,2 \\
\hline Мурманская область & 20,3 & 54,8 & 25,2 & 63,7 \\
\hline Калининградская область & 21,2 & 79,4 & 19,9 & 74,1 \\
\hline Новгородская область & 17,2 & 90,7 & 16,0 & 81,0 \\
\hline Республика Коми & 28,7 & 52,1 & 51,5 & 97,9 \\
\hline Вологодская область & 34,9 & 100,5 & 35,2 & 98,1 \\
\hline Архангельская область & 35,6 & 80,2 & 40,7 & 98,6 \\
\hline Псковская область & 14,7 & 99,5 & 14,7 & 107,3 \\
\hline Республика Карелия & 19,0 & 102,4 & 20,1 & \\
\hline Источники: законы субъектов РФ о региональном бюджете на 2014-2016 и на 2015-2017 гг.; расчёты автора. \\
\hline
\end{tabular}


Выступая на расширенной коллегии Минфина РФ 8 апреля 2013 г., Председатель Совета Федерации В.И. Матвиенко задала справедливый вопрос главному финансовому ведомству: «Минфин не должен стоять в стороне. Почему мы не остановили безудержные заимствования ряда регионов, которые практически стали банкротами?» [3].

К сожалению, системные меры по решению проблемы бюджетного кризиса регионов Правительством РФ до сих пор не предложены.

Напротив, в «Программе повышения эффективности управления общественными (государственными и муниципальными) финансами на период до 2018 года» совершенно открыто говорится о том, что «основная часть государственных полномочий должна быть закреплена за субъектами Российской Федерации в качестве собственных».

Похоже, что решать проблему повышения эффективности управления региональными финансами правительственный аппарат намерен за счёт постепенной окончательной передачи финансирования своих функций субъектам РФ, не осознавая последствий, к которым может привести рост числа финансово не обеспеченных обязательств и без того непомерно обременённых региональных бюджетов [18].

Концептуальные аспекты действий, необходимых для корректировки проводимой налогово-бюджетной политики, имеют аргументированное обоснование в большом числе трудов представителей научного сообщества $[1,2,4,5,6,8,9,17,19]$.

Как видится, на региональном уровне первоочередными должны стать меры, обеспечивающие адекватное законодательное обеспечение субнациональных бюджетных систем. Укрупнённый перечень этих мер можно представить в виде трёх блоков.
1. Передача на региональный уровень дополнительных налоговых доходов ${ }^{10}$, а именно:

- закрепление за бюджетами регионов поступлений налога на прибыль в полном объёме ${ }^{11}$ на том основании, что в формировании доходов федерального бюджета доля этого платежа не превышает 3\%;

- повышение стандартной ставки НДС (к примеру, с 18 до 20\%) либо отмена возмещения из федерального бюджета НДС экспортёрам сырьевых ресурсов и направление дополнительных сборов НДС на увеличение выравнивающих дотаций субъектам РФ или их распределение между регионами на подушевой основе, как это происходит в Германии;

- введение налога на роскошь, которое правительство так и не решается предпринять ${ }^{12}$.

2. Увеличение объёма финансовой помощи из федерального бюджета. В приоритетном порядке должны выделяться не бюджетные кредиты, а трансферты, поскольку в случае предоставления новых кредитов для погашения уже имеющейся задолженности ситуация будет воспроизводиться.

Одной из мер в данном направлении может стать пересмотр действующего порядка использования целевых трансфертов. Неравномерное в течение года ${ }^{13}$ выделение федеральным центром межбюджетных трансфертов приводит к тому,

10 В соответствии с Законом о федеральном бюджете, в 2015-2017 гг. на федеральном уровне будет централизовано 72,4\% доходов бюджетной системы РФ

${ }^{11}$ В соответствии с Бюджетным кодексом РФ 2\% налога на прибыль, исчисленного по ставке $20 \%$, зачисляется в федеральный бюджет, а $18 \%$ - в бюджет субъекта РФ

${ }^{12} \mathrm{O}$ необходимости введения налога на роскошь в первой половине 2013 г. Президент РФ заявлял ещё в Послании Федеральному Собранию 12 декабря 2012 г.

${ }^{13}$ По нашим расчётам, в 2011-2013 гг. более 30\% федеральных трансфертов в региональный бюджет Вологодской области было перечислено в 4 квартале, что сопоставимо со средним показателем по субъектам РФ. 
что субъекты не могут своевременно ими распорядиться, в результате чего в соответствии с бюджетным законодательством неиспользованные остатки возвращают в федеральный бюджет.

В Вологодской области объём возвратов за 2008-2013 гг. увеличился в 8,4 раза с 56 до 476 млн. руб.

Более серьёзного внимания со стороны центрального правительства требуют вопросы софинансирования инвестиционных программ территорий. По данным Федерального казначейства, объём субсидий, выделенных субъектам РФ из федерального бюджета на капиталовложения, за 20122014 гг. сократился со 199 до 56 млрд. руб., или в 3,6 раза (в Вологодской области - с 825 до 184 млн. руб., или в 4,5 раза). Безусловно, такое резкое сжатие инвестиционных трансфертов создаст долговременные риски для устойчивого роста налогового потенциала.

3. Инвентаризация расходных полномочий с последующей передачей части из них на федеральный уровень.

По оценкам Института экономики Уральского отделения РАН, с 2000 г. не было случая передачи Федерацией полно- мочий регионам и муниципалитетам со $100 \%$-ной финансовой обеспеченностью ресурсами [20].

Весомым облегчением для социальной нагрузки региональных бюджетов могла бы стать передача на уровень Федерации расходов по уплате страховых взносов на обязательное медицинское страхование неработающего населения. Данные расходы, например, в Вологодской области превалируют в структуре расходов регионального бюджета на здравоохранение, занимая 56\% (в РФ-42\%).

По нашим оценкам, реализация только одних вышеперечисленных первоочередных мер позволит увеличить ежегодные доходы региональных бюджетов в среднем на 1,2 трлн. руб. (табл. 10).

В процессе реализации этих мер следует переходить к коренной переработке Налогового и Бюджетного кодексов РФ с целью изменения подходов к налогообложению прибыли крупного бизнеса, установления валютного контроля, введения прогрессивной шкалы подоходного налога, наведения порядка в недропользовании, отмены налоговых льгот и преференций для высокодоходных хозяйствующих субъектов и т.д.

Таблица 10. Источники дополнительных доходов региональных бюджетов субъектов РФ, млрд. руб. в год

\begin{tabular}{|l|c|}
\hline \multicolumn{1}{|c|}{ Источник } & 0ценка \\
\hline Зачисление в полном объёме собранного на территории региона налога на прибыль & $350 *$ \\
\hline Повышение ставки НДС или отмена возмещения НДС сырьевым экспортёрам & $400-450 *$ \\
\hline Введение налога на роскошь & $200-250^{* *}$ \\
\hline Оставление неиспользованных целевых межбюджетных транссрертов в региональных бюджетах & $35-40^{*}$ \\
\hline $\begin{array}{l}\text { Передача на федеральный уровень полномочий по уплате страховых взносов на ОМС неработа- } \\
\text { ющего населения }\end{array}$ & $500^{*}$ \\
\hline Итого & $1135-1240$ \\
\hline $\begin{array}{l}\text { * Оценка выполнена исходя из динамики показателя за 2011-2013 гг. } \\
\text { ** Согласно законопроекту, подготовленному депутатом Госдумы РФ д.э.н. О.Г. Дмитриевой совместно с представителями пар- } \\
\text { тии «Справедливая Россия», под действие налога на роскошь попадают объекты недвижимости стоимостью свыше } 30 \text { млн. руб. } \\
\text { и транспортные средства стоимостью свыше 3 млн. руб. Это примерно 200 тыс. квартир и особняков и около 100 тыс. транс- } \\
\text { портных средств. Причём их владельцы - это сотые доли процента населения, сверхбогатые россияне, владеющие объектами } \\
\text { роскоши, а не средний класс. По своему объёму поступления налога на роскошь от небольшого числа состоятельных лиц будут } \\
\text { сопоставимы с поступлениями налогов от всех упрощённых режимов, уплачиваемыми миллионами малых предпринимателей } \\
\text { и фермеров. }\end{array}$ \\
\hline
\end{tabular}


Безусловно, материализация указанных резервов в большей степени зависит от усилий федерального центра. Однако это не освобождает региональные власти от проведения ответственной бюджетной политики. Применительно к Вологодской области основные направления такой политики должны включать следующее.

Bo-nервых, активный поиск всех возможных источников увеличения собираемости налоговых доходов. По данным Департамента финансов области, на конец 2014 г. задолженность налогоплательщиков региона по уплате налогов в бюджетную систему РФ превысила 2 млрд. руб., а потери бюджета от применения «серых» схем оплаты труда достигли 5 млрд. руб. Этих средств вполне хватило бы не только на покрытие текущего дефицита, но и на финансовое обеспечение инаугурационных указов Президента в 2015 г.

В целях усиления мобилизующей функции неналоговых доходов следует реализовать ряд мер административного характера, в частности: пересмотреть законодательную базу; проиндексировать ставки отдельных видов платежей; исключить факты передачи областного имущества в безвозмездное пользование федеральным структурам.

Bo-вторых, дальнейшую оптимизацию бюджетных расходов на управление. Динамичное увеличение общегосударственных затрат, в отличие от других расходных статей, указывает на имеющиеся резервы их сокращения (рис. 13).

По последним данным Вологдастата, за январь-сентябрь 2014 г. по сравнению с аналогичным периодом предыдущего года численность работников органов государственного управления в области выросла с 9,8 до 16,9 тыс. человек, то есть в 1,7 раза.

Средняя заработная плата одного работника аппарата управления, включая весь штатный персонал, составила 41,7 тыс. руб. при средней зарплате по экономике 25,7 тыс. руб. Заработная плата чиновников Правительства Вологодской области, замещаю-

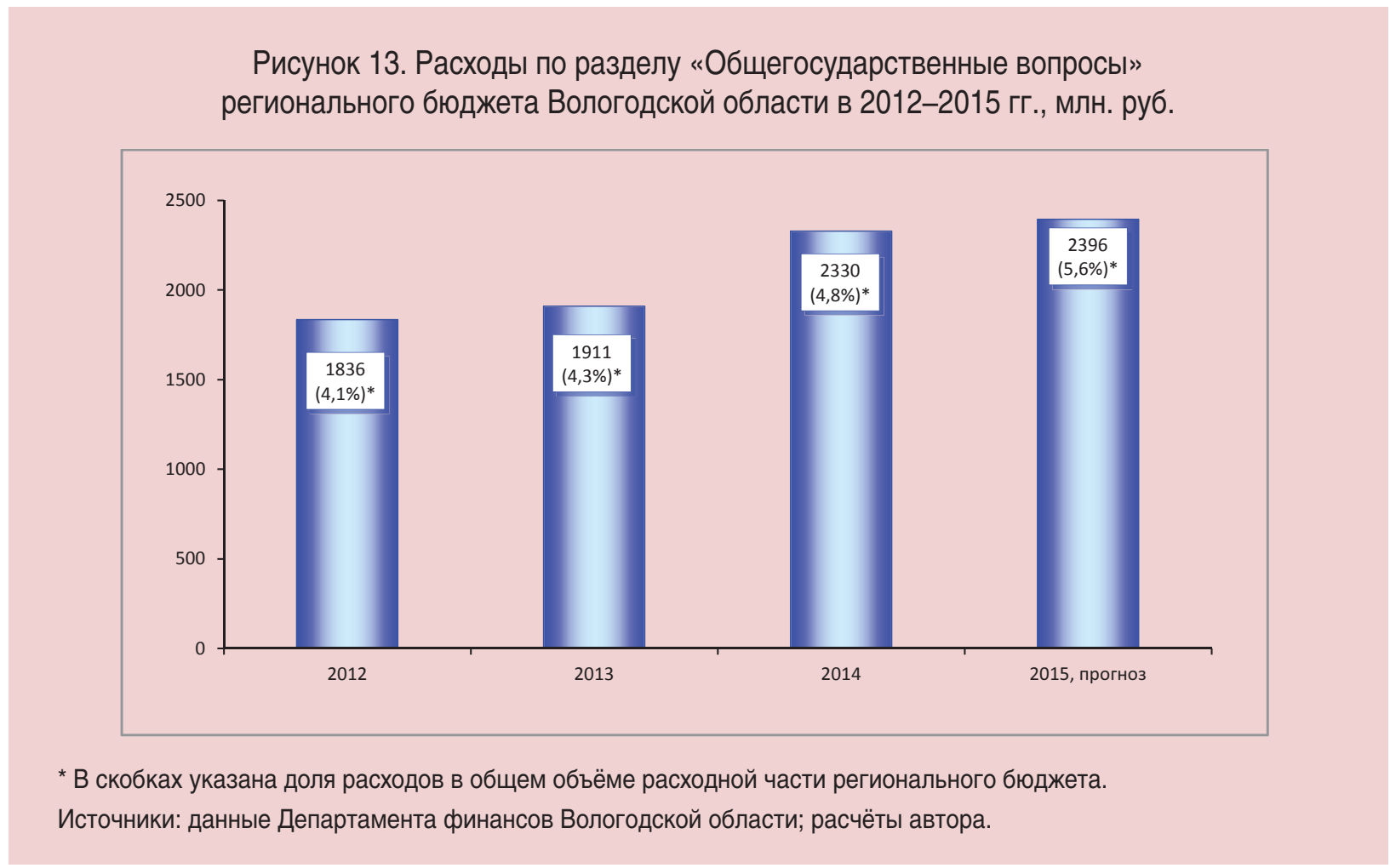


щих государственные должности, достигла 301 тыс. руб. и превзошла среднестатистический показатель по региону в 12 раз.

$\boldsymbol{B}$-третьих, усиление ответственности распорядителей бюджетных средств за ненадлежащий уровень кассового исполнения расходов. При хроническом бюджетном дефиците ежегодно не осваивается порядка 2 млрд. руб. утверждённых ассигнований областного бюджета.

Серьёзную озабоченность вызывает бюджетная дебиторская задолженность, объём которой на начало 2014 г. достиг 1,1 млрд. руб. Почти вся эта сумма приходится на оплату авансов по заключённым контрактам и на расчёты по кредитам, выданным из областного бюджета.

Укрепление финансовой основы регионов должно стать центральным аспектом повышения эффективности государственного управления.

Продолжение политики бюджетной консолидации неизбежно приведёт к затяжному долговому кризису территориальных бюджетов, а в конечном итоге к дефолту регионов и дестабилизации экономики страны. Одновременно ощущается потребность в консолидации усилий российских регионов по изменению политики федерального центра.

\section{Литература}

1. Букина, И.С. Парадоксы финансовой политики в РФ / И.С. Букина // Федерализм. - 2014. - № 2. C. 25-34.

2. Бюджетная трёхлетка 2015-2017: императив «реверсирования» социально-экономического курса проигнорирован и на сей раз: редакционная статья // Российский экономический журнал. - 2014. - № 5. C. 3-21.

3. Выступление Матвиенко В.И. на расширенной коллегии Минфина РФ по вопросу «Об итогах исполнения федерального бюджета за 2012 год и задачах органов финансовой системы РФ на 2013 год» 8 апреля 2013 г. [Электронный ресурс]. - Режим доступа: http://www.council.gov.ru/media/files/

4. Дмитриева, О.Г. Экономические кругообороты и финансовые пылесосы / О.Г. Дмитриева // Вопросы экономики. - 2013. - № 7. - С. 49-62.

5. Зюганов, Г.А. Проект деградации / Г.А. Зюганов // Советская Россия. - 2014. - 14 октября.

6. Ильин, В.А. Бюджетный кризис регионов в 2013-2015 годах - угроза безопасности России / В.А. Ильин, А.И. Поварова // Экономические и социальные перемены: факты, тенденции, прогноз. - 2012. - № 6. C. $30-41$.

7. Ильин, В.А. Проблемы регионального развития как отражение эффективности государственного управления / В.А. Ильин, А.И. Поварова // Экономика региона. - 2014. - № 3. - С. 48-63.

8. Кашин, В.А. Налоговая система - угроза национальной безопасности России / В.А. Кашин, М.Д. Абрамов [Электронный ресурс]. - Режим доступа: http://www.modern-rf.ru/netcat_files/93/47/

9. Ореховский, П.А. Российская налоговая система и грядущий кризис региональных финансов / П.А. Ореховский // Федерализм. - 2014. - № 1. - С. 141-150.

10. Об областном бюджете на 2015 год и плановый период 2016 и 2017 годов: закон Вологодской области от 22.12.2014 г. № 3532-Ф3.

11. О прогнозе социально-экономического развития Вологодской области на 2015-2017: постановление Правительства Вологодской области от 27.10.2014 г. № 954.

12. Официальный сайт Департамента финансов Вологодской области. - Режим доступа: http://df35.ru/

13. Официальный сайт Министерства экономического развития РФ. - Режим доступа: http://economy.gov. $\mathrm{ru} / \mathrm{minec} /$ activity/sections/macro/prognoz/

14. Официальный сайт ПАО «Северсталь». - Режим доступа: http://www.severstal.ru/

15. Официальный сайт Федерального казначейства России. - Режим доступа: http://www.roskazna.ru/

16. Официальный сайт Федеральной налоговой службы России. - Режим доступа: http://www.nalog.ru/

17. Петров, Ю.А. К формированию новой экономической модели: рестрикция бюджетных расходов или повышение собираемости налогов? / Ю.А. Петров // Российский экономический журнал. - 2013. № 4. - C. 24-39. 
18. Поварова, А.И. Об условиях и мерах повышения эффективности общественных финансов (критические заметки) / А.И. Поварова // Экономист. - 2014. - № 3. - С. 68-71.

19. Солянникова, С.П. Управление государственными финансами: заявленные принципы и реальность / С.П. Солянникова // Экономист. - 2014. - № 4. - С. 44-58.

20. Татаркин, А.И. Диалектика государственного и рыночного регулирования социально-экономического развития регионов и муниципалитетов / А.И. Татаркин // Экономика региона. - 2014. - № 1. - С. 9-30.

Povarova A.I.

\section{Regional budget for 2015-2017: doing away with deficit or doing away with development?}

Anna Ivanovna Povarova - Senior Research Associate, Head of the Sector for Research into the Issues of Public Finance, Federal State Budgetary Institution of Science Institute of Socio-Economic Development of Territories of Russian Academy of Science (56A, Gorky Street, Vologda, 160014, Russia. aip150663@yandex.ru)

Abstract. Regional budget in the Vologda Oblast for 2015-2017 was formed under difficult socioeconomic conditions caused not only by a longstanding dependence of Russia's economy and its budget system on the external economic environment, but also by a number of new factors associated with the aggravation of geopolitical tensions and the application of sectoral sanctions by Western countries.

Despite an uncertainty in economic development trends, the new budget is announced to be deficitfree. It would seem that the balance of revenues and expenditures, a fundamental principle of the budget system, has been achieved. However, an analysis of the expenditure part of the budget shows that the balance is achieved at the expense of introducing the austerity regime followed by the restriction of all directions of funding. For 2015-2017 the share of the regional budget expenditures in GRP will decrease to 9.8\% vs. $13.6 \%$ in 2014. If macroeconomic dynamics maintains its downward trend, such fiscal policy in the long term will suppress the economy even more significantly and will ultimately lead to the taxable capacity reduction.

Under the conditions of economic activity slowdown, even if the budget is balanced, it will not be possible to neutralize the cyclical risks connected with the receipt of profit tax from the metallurgical and chemical industries that are integrated into the world economy and act as the major budget revenue generating industries in the region. Simple calculations prove that at the current high level of debt load it will be extremely difficult for the government to overcome the dependence on borrowed funds; therefore, it seems rather doubtful that the budget balance over the forecast period can be achieved.

The author analyzes several laws on the regional budget* and comes to a conclusion that the fiscal policy pursued by the federal government is flawed because it focuses on fiscal functions rather than on stimulating and regulating functions that promote economic growth.

The growing problems at the regional level will sooner or later require that the center make definite decisions. The article substantiates practical recommendations for stabilizing the regional and local budget systems; this stabilization should be accompanied by the adoption of measures to adjust fiscal policy.

Key words: regional budget, deficit, loans, debt load, fiscal policy adjustment.

* Povarova A.I. Formirovanie regional'nogo byudzheta v usloviyakh krizisa [Formation of Regional Budget in Crisis]. Ekonomicheskie i sotsial'nye peremeny: fakty, tendentsii, prognoz [Econoic and Social Changes: Facts, Trends, Forecast], 2010, no. 2, pp. 101-114; Povarova A.I. Trekhletnii byudzhet: zhdat' li stabil'nosti? [The Three-Year Budget: Should We Wait for Stability?]. Ibidem, 2011, no. 2, pp. 20-36; Povarova A.I. Regional'nyi byudzhet 2012-2014: stabil'nost' otkladyvaetsya [Regional Budget of 2012 - 2014: Stability is Delayed]. Ibidem, 2012, no. 3, pp. 39-58; Povarova A.I. Regional'nyi byudzhet 2013-2015: stabil'nost' ili vyzhivanie? [Regional Budget for 2013 - 2015: Stability or Survival?]. Ibidem, 2013, no. 1, pp. 36-55. 


\section{References}

1. Bukina I.S. Paradoksy finansovoi politiki v RF [The Paradoxes of Financial Policy in the Russian Federation]. Federalizm [Federalism], 2014, no. 2, pp. 25-34.

2. Byudzhetnaya trekhletka 2015-2017: imperativ "reversirovaniya” sotsial'no-ekonomicheskogo kursa proignorirovan i na sei raz: redaktsionnaya stat'ya [The Three-Year Budget 2015-2017: the Imperative of "Reversing" the Socio-Economic Course Ignored Once Again: Editorial]. Rossiiskii ekonomicheskii zhurnal [Russian Economic Journal], 2014, no. 5, pp. 3-21.

3. Vystuplenie Matvienko V.I. na rasshirennoi kollegii Minfina RF po voprosu "Ob itogakh ispolneniya federal'nogo byudzheta za 2012 god i zadachakh organov finansovoi sistemy RF na 2013 god" 8 aprelya 2013 g. [The Speech of V.I. Matvienko at the Expanded Board of the Ministry of Finance of the Russian Federation "On the Results of Execution of the Federal Budget for 2012 and the Tasks of the Financial Authorities of the Russian Federation for 2013”, April 8, 2013]. Available at: http://www.council.gov.ru/media/files/

4. Dmitrieva O.G. Ekonomicheskie krugooboroty i finansovye pylesosy [Economic Turnovers and Financial Vacuum Cleaners]. Voprosy ekonomiki [Issues of the Economy], 2013, no. 7, pp. 49-62.

5. Zyuganov G.A. Proekt degradatsii [Degradation Project]. Sovetskaya Rossiya [Soviet Russia], 2014, October 14.

6. Ilyin V.A., Povarova A.I. Byudzhetnyi krizis regionov v 2013-2015 godakh - ugroza bezopasnosti Rossii [Budget Crisis of the Regions in 2013 - 2015: a Threat to Russia's Security]. Ekonomicheskie i sotsial'nye peremeny: fakty, tendentsii, prognoz [Economic and Social Changes: Facts, Trends, Forecast], 2012, no. 6, pp. 30-41.

7. Ilyin V.A., Povarova A.I. Problemy regional'nogo razvitiya kak otrazhenie effektivnosti gosudarstvennogo upravleniya [Problems of Regional Development as the Reflection of the Effectiveness of Public Administration]. Ekonomika regiona [Economy of the Region], 2014, no. 3, pp. 48-63.

8. Kashin V.A., Abramov M.D. Nalogovaya sistema - ugroza natsional'noi bezopasnosti Rossii [Tax System - a Threat to Russia's National Security]. Available at: http://www.modern-rf.ru/netcat_files/93/47/

9. Orekhovskii P.A. Rossiiskaya nalogovaya sistema i gryadushchii krizis regional'nykh finansov [Russian Fiscal System and the Coming Crises of Regional Finances]. Federalizm [Federalism], 2014, no. 1, pp. 141-150.

10. Ob oblastnom byudzhete na 2015 god i planovyi period 2016 i 2017 godov: zakon Vologodskoi oblasti ot 22.12.2014 g. № 3532-FZ [On the Oblast Budget for 2015 and for the Planned Period of 2016 and 2017: the Law of the Vologda Oblast of December 22, 2014 No. 3532-FZ].

11. O prognoze sotsial'no-ekonomicheskogo razvitiya Vologodskoi oblasti na 2015-2017: postanovlenie Pravitel'stva Vologodskoi oblasti ot 27.10.2014 g. № 954 [On the Forecast of Socio-Economic Development of the Vologda Oblast in 2015-2017: Resolution of the Government of the Vologda Oblast of October 27, 2014 No. 954].

12. Ofitsial'nyi sait Departamenta finansov Vologodskoi oblasti [Official Website of the Vologda Oblast Department of Finance]. Available at: http://df35.ru/

13. Ofitsial'nyi sait Ministerstva ekonomicheskogo razvitiya $R F$ [Official Website of the Ministry of Economic Development of the Russian Federation]. Available at: http://economy.gov.ru/minec/activity/sections/macro/ prognoz/

14. Ofitsial'nyi sait PAO "Severstal” [Official Website of PAO Severstal]. Available at: http://www.severstal.ru/

15. Ofitsial'nyi sait Federal'nogo kaznacheistva Rossii [Official Website of the Federal Treasury of Russia]. Available at: http://www.roskazna.ru/

16. Ofitsial'nyi sait Federal'noi nalogovoi sluzhby Rossii [Official Website of the Federal Tax Service of Russia]. Available at: http://www.nalog.ru/

17. Petrov Yu.A. K formirovaniyu novoi ekonomicheskoi modeli: restriktsiya byudzhetnykh raskhodov ili povyshenie sobiraemosti nalogov? [About Shaping a New Economic Model: Restriction of Budget Expenditures or Better Fiscal Performance?]. Rossiiskii ekonomicheskii zhurnal [Russian Economic Journal], 2013, no. 4, pp. 24-39.

18. Povarova A.I. Ob usloviyakh i merakh povysheniya effektivnosti obshchestvennykh finansov (kriticheskie zametki) [About the Conditions and Measures to Improve the Effectiveness of Public Finance (Critical Notes)]. Ekonomist [The Economist], 2014, no. 3, pp. 68-71.

19. Solyannikova S.P. Upravlenie gosudarstvennymi finansami: zayavlennye printsipy i real'nost' [Public Finance Management: Declared Principles and Reality]. Ekonomist [The Economist], 2014, no. 4, pp. 44-58.

20. Tatarkin A.I. Dialektika gosudarstvennogo i rynochnogo regulirovaniya sotsial'no-ekonomicheskogo razvitiya regionov i munitsipalitetov [Dialectics of Public and Market Regulation of a Region and Municipality Socioeconomic Development]. Ekonomika regiona [Economy of the Region], 2014, no. 1, pp. 9-30. 